\title{
Uji Toksisitas Bahan Aktif Niklosamida Terhadap Crustacea Sebagai Water Treatment dalam Budidaya Udang Vannamei (Litopenaus vannamei)
}

\section{Toxicity Test Active Ingredients of niclosamide Against crustacean For Water Treatment in Cultivating Vannamei (Litopenaus vannamei)}

\author{
Aan Fahrizki ${ }^{1}$, Herman Yulianto ${ }^{2}$, dan Asep saefulloh ${ }^{2}$ \\ 1) Mahasiswa Jurusan Budidaya Perairan Fakultas Pertanian Universitas Lampung \\ ${ }^{2)}$ Dosen Jurusan Budidaya Perairan Fakultas Pertanian Universitas Lampung
}

\begin{abstract}
This study aims to determine the level of toxicity of the active ingredient based niclosamide on the value LC50-24h against crustaceans and the duration of the residual effect of niclosamide in water. Methods This study used a completely randomized design with 4 different concentration levels and 0 ppm as a control. Toxicity tests using a concentration of 1.7783; 3.1623; 5.6235 and $10.0002 \mathrm{ppm}$. To determine the duration of the test using the residual effects of detoxification. In the detoxification test stick with a concentration in the toxicity test. Probit analysis results in test animals showed values (LC50) - 24 hours amounted to 3.6282 ppm, while the length of the residual effects of niclosamide in water for 96 hours.
\end{abstract}

Kata kunci : Crustacea, niclosamide, and toxicity

Diterima: 30-12-2014 : disetujui 23-10-2015

\section{PENDAHULUAN}

Udang merupakan komoditas ekspor andalan pemerintah untuk meningkatkan devisa negara sehingga pengembangan ekspornya menjadi perhatian utama. Dipilihnya udang sebagai andalan utama peningkat devisa tentu memiliki alasan. Salah satunya adalah Indonesia memiliki luas lahan budidaya yang potensial untuk udang. Di Indonesia setidaknya terdapat $913.000 \mathrm{Ha}$ lahan lainya yang potensial untuk budidaya. Tentunya hal ini dapat menjadi faktor pendukung dan pemicu perkembangan industri budidaya udang yang selaras dengan perkembangan ilmu pengetahuan baik di Indonesia, Asia bahkan masyarakat dunia secara umum (SEAFDEC, 2005).

Secara umum Indonesia memiliki peluang yang sangat baik untuk memposisikan diri sebagai salah satu produsen dan eksportir utama produk perikanan, terutama udang. Kenyataan ini sesuai dari besarnya permintaan produk udang, baik di pasar domestik maupun pasar ekspor. Besarnya permintaan terhadap produk perikanan ini disebabkan oleh geseran selera konsumen dari daging 
merah menjadi white meat (daging udang atau ikan), terutama setelah merebaknya berbagai penyakit ternak (Amri, 2004).

Dewasa ini proses kegiatan budidaya udang banyak kendala yang ditemukan, salah satunya adalah keberadaan hama dan penyakit. Serangan penyakit dari hama dapat mengakibatkan kematian masal hingga mencapai $100 \%$ dalam waktu yang sangat singkat yaitu hanya 2 hari sejak gejala pertama tampak. Udang yang terserang biasanya berenang ke tepi dekat pematang, lemah, kehilangan nafsu makan dan akhirnya mati. Penularan penyakit yang sangat cepat, menyebabkan sulitnya penanggulangan penyakit.

Penggunaan crustacide (pembasmi crustacea) pada kegiatan budidaya udang dalam proses water perlakuan di tandon air ditunjukan untuk mengendalikan hama karier berupa crustacea liar, menekan hama kompetitor dan memutus siklus hidup vektor penyakit yang berpotensi membawa virus kedalam tambak budidaya. Bahan yang digunakan tentunya yang mempunyai sifat mudah terurai sehingga tidak menimbulkan residu kimia berbahaya dan tentunya diperbolehkan oleh badan pangan dunia atau Food and Agriculture Organization (FAO) supaya produk udang Indonesia dapat di terima oleh pasar ekspor. Salah satu bahan aktif pestisida yang tidak terdaftar dalam larangan oleh FAO adalah niklosamida.

Niklosamida adalah jenis mollukisida yang sedang dikembangkan untuk mengantikan peran organoklorin yang telah dilarang pengunaannya. Jenis mollukisida niklosamida ini ditunjukan untuk mengendalikan moluska atau siput. Di Indonesia niklosamida digunakan untuk memberantas keong mas atau siput murbei (Pamacea sp.) yang merupakan hama dalam produksi padi. Sedangkan di Amerika, niklosamida biasa digunakan sebagai kontrol populasi ikan lamprey laut (Petromyzon marinus) pada aliran anak sungai danau Great (Schreier et al., 2000). Niklosamida dengan nama kimia benzoic acid, 2- [(3,5- dichloro-2-nitrophenyl)amino] dengan rumus empiris $\mathrm{C}_{13} \mathrm{H}_{8} \mathrm{Cl}_{2} \mathrm{~N}_{2} \mathrm{O}_{4}$ (Worthing, 1987) dengan rumus empiris $\mathrm{C}_{13} \mathrm{H}_{8} \mathrm{Cl}_{2} \mathrm{~N}_{2} \mathrm{O}_{4}$ (Worthing, 1987). Berdasarkan beberapa hal tersebut maka diperlukan kajian tentang nilai toksisitas niklosamida untuk sterilisasi air tambak serta lamanya residu dalam air.

\section{METODE}

Adapun alat dan bahan yang digunakan selama penelitian adalah toples 2,5 L 20 buah, box bioassay dengan air lift 2 buah, batu aerasi 20 buah, heater 1 buah, pipet mikro + tip P1000, jaring 1 buah, baskom plastik 1 buah, benur Udang vannamei ukuran PL $9 \pm 400$ ekor, larutan stock niklosamida 1000 ppm dan air laut.

Metode yang digunakan dalam penelitian ini adalah eksperimental laboratoris dengan menghgunakan Rancangan Acak Lengkap (RAL) dengan mengacu pada persamaan Hanafiah (2008) dengan persamaan yang digunakan adalah sebagai berikut :

$$
\mathrm{Yij}=\mu+\tau \mathrm{i}+\mathrm{Eij}
$$

Keterangan :

Yij : Pengaruh perlakuan ke-I dan ulangan ke-j

$\mu \quad$ : Rataan Umum

$\tau$ i : Pengaruh Konsentrasi pestisida ke-i

Eij : Galat Percobaan 
Aan Fahrizki dkk: Uji Toksisitas Bahan Aktif Niklosamida Terhadap Crustacea Sebagai Water Treatment...

Pada penelitian ini dilakukan 3 kali pengujian untuk mendapatkan nilai $\mathrm{LC}_{50}-24$ jam uji yang dilakukan antara lain adalah sebagai berikut : uji penentuan nilai kisaran, uji definitif (toksisitas bahan uji), uji detoksifikasi. Metode yang digunakan pada penelitian ini adalah Rancangan Acak Lengkap (RAL). Dalam setiap uji menggunakan 5 tingkat konsentrasi yang berbeda dan diulang sebanyak 4 kali. Penelitian ini melalui 3 tahap pengujian yaitu uji penentuan kisaran, uji toksistas dan uji detoksifikasi. Uji penentuan kisaran bertujuan untuk mendapatkan konsentrasi ambang atas $\left(\mathrm{LC}_{100^{-}}-24\right.$ jam) dan konsentrasi ambang bawah ( $\mathrm{LC}_{0}-24$ jam) pada hewan uji yaitu PL 9 udang vannamei. Sedangkan pada uji definitif (uji toksisitas) bertujuan untuk menentukan nilai LC50- 24 jam dengan menggunakan deret konsentrasi yang besarnya berada dikisaran ambang atas dan ambang bawah. Perhitungan dilakukan dengan mengacu pada persamaan Finney (1971) sebagai berikut :

$$
\log _{\frac{1}{n}}^{N}=\mathrm{k} \log _{\frac{a}{n}} ; \frac{a}{n}=\frac{b}{a}=\frac{c}{b}=\frac{d}{c}
$$

Dimana ;

$\mathrm{N}$ : Konsentrasi ambang atas

$\mathrm{n}$ : Konsentrasi ambang bawah

a : Konsentrasi yang dikehendaki setelah ambang batas bawah

k: Jumlah konsentrasi yang diuji (mis. 4; a, b, c, d, )

$\mathrm{a}, \mathrm{b}, \mathrm{c}, \mathrm{d}$, adalah konsentrasi yang diuji dengan nilai a sebagai konsentrasi terkecil

Hasil uji toksisitas merupakan angka acuan untuk menhitung nilai lethal consentration dengan analisis probit. Hubungan nilai logaritma konsentrasi uji dengan persentasi mortalitas (dalam probit), merupakan fungsi linear : $\mathrm{Y}=\mathrm{a}+\mathrm{bX}$. Nilai $\mathrm{LC}_{50}-24$ jam diperoleh dari anti $\log \mathrm{m}$. Nilai m merupakan nilai $X$ pada saat kematian sebesar 50\% sehingga fungsi linearnya adalah $5=a+b X$. Untuk menentukan nilai a maupun b digunakan persamaan Finney (1971) sebagai berikut :

$$
\begin{aligned}
& \mathrm{b}=\frac{\Sigma X Y-\frac{1}{n}(\Sigma X \Sigma Y)}{\Sigma X^{2}-\frac{1}{n}(\Sigma X)^{2}} \\
& a=\frac{1}{n}(\Sigma Y-b \Sigma X) \\
& m=\frac{5-a}{b}
\end{aligned}
$$

$\mathrm{LC}_{50^{-}} 24 \mathrm{jam}=$ anti $\log \mathrm{m}$

Dengan $\mathrm{y}, \mathrm{x}, \mathrm{a}, \mathrm{b}$ dan $\mathrm{m}$ berturut-turut adalah probit kematian hewan uji, logaritma konsentrasi uji, konsentrasi regresi, slope/ kemiringan regresi , dan logaritma konsentrasi (x) pada probit mortalitas (y) 50\% (y=5).

Setelah uji toksisitas maka dilanjutkan dengan uji detoksifikasi yang bertujuan untuk mengetahui lamanya efek residu bahan aktif niklosamida dalam air. Konsentrasi yang digunakan pada uji detoksifikasi ini sama dengan saat uji toksisitas. Metode uji detoksifikasi ini dengan melakukan pengamatan mortalitas selama 24 jam, apabila pada salah satu konsentrasi masih terdapat mortalitas makan semua hewan uji diganti dengan yang baru dan dilakukan sampai semua hewan uji tidak mengalami kematian pada 4 konsentrasi yang digunakan. 


\section{HASIL DAN PEMBAHASAN}

\section{Hasil Uji Penentuan Kisaran}

Pada penelitian uji toksisitas bahan aktif niklosamida ini didapatkan data $\mathrm{Lc}_{50}-24$ jam niklosamida terhadap crustacea, efek subletal niklosamida terhadap crustacea dan data waktu efek residu bahan aktif niklosamida dalam air. Sebelum dilakukan pengamatan mortalitas untuk mendapatkan nilai $\mathrm{Lc}_{50}-24$ jam dilakukan uji penentuan kisaran yang bertujuan untuk mendapatkan nilai ambang atas dan nilai ambang bawah yang akan digunakan pada uji utama (uji toksisitas). Penentuan kisaran dilakukan dengan menyiapkan hewan uji berupa PL-9 udang vaname sebanyak \pm 400 ekor yang dimasukan kedalam wadah pemeliharaan berupa toples sebanyak 20 buah, setiap toples diisi dengan 20 ekor hewan uji. Konsentrasi yang digunakan dalam uji penentuan kisaran ini adalah sebagai berikut 0 ppm(kontrol);1 ppm; 4 ppm; 7 ppm; dan 10 ppm. Pengamatan mortalitas dilakukan pada waktu pengamatan 1, 6, 12 dan 24 jam setelah perlakuan dilakukan.

Dari uji penentuan kisaran yang dilakukan didapatkan konsentrasi ambang atas $\left(\mathrm{LC}_{100}-24\right)$

(N) yaitu konsentrasi terendah yang dapat mematikan $100 \%$ dalam waktu 24 jam dan nilai ambang bawah $\left(\mathrm{LC}_{0}-24\right)$ yaitu konsentrasi tertinggi dari niklosamida yang tidak mematikan hewan uji selama 24 jam dan ambang bawah seperti pada tabel 1.

Tabel 1. Mortalitas (\%) hewan uji pada uji ambang batas konsentrasi niklosamida

\begin{tabular}{ccccccc}
\hline $\begin{array}{c}\text { Konsentrasi } \\
(\mathrm{ppm})\end{array}$ & $\begin{array}{c}\text { N hewan uji } \\
\text { (ekor) }\end{array}$ & - & & \multicolumn{4}{c}{ Waktu pengamatan (jam) } & \\
\cline { 6 - 7 } & 80 & 0 & 0 & 0 & 0 & 0 \\
1 & 80 & 0 & 0 & 0 & 0 & 0 \\
4 & 80 & 0 & 8,75 & 17,5 & 33,75 & 38,75 \\
7 & 80 & 0 & 33,75 & 48,75 & 68,75 & 80 \\
10 & 80 & 0 & 65 & 88,75 & 95 & 100 \\
\hline
\end{tabular}

Dari tabel 1. dapat dilihat bahwa konsentrasi 10 ppm dapat membunuh hewan uji sebesar $100 \%$ pada waktu pengamatan jam ke 24 , sementara konsentrasi 7 ppm hanya mematikan hewan uji sebesar $80 \%$ selama 24 jam pengamatan. Sehingga konsentrasi $10 \mathrm{ppm}$ dipilih sebagai ambang atas karena dapat mematikan hewan uji sebesar $100 \%$ dalam waktu 24 jam. Sedangkan untuk ambang bawah dipilih konsentrasi 1 ppm karena tidak mematikan hewan uji selama pengamatan 24 jam. Sehingga konsentrasi untuk uji toksisitas letal dapat diketahui dengan menggunakan persamaan 2 dan 3.

\section{Hasil Uji Definitif (Toksisitas Hewan Uji)}

Uji definitif dilakukan setelah didapatkan nilai ambang bawah dan ambang atas bahan uji nikosamida. Berdasarkan hasil uji yang telah dilakukan, didapatkan nilai konsentrasi bahan uji yang diperlukan untuk menentukan nilai $\mathrm{LC}_{50}-24$ jam. Dalam penentuan rentang konsentrasi harus mempunyai logaritma yang tetap agar tidak terjadi kerancuan dalam menentukan $\mathrm{LC}_{50}-24$ jam bahan uji tersebut. Interval konsentrasi pendugaan $\mathrm{LC}_{50}-24$ jam yang digunakan ditentukan dengan rumus Hubert, (1979) dalam Yunita, dkk (2009). Konsentrasi yang digunakan pada uji utama (uji toksisitas) yaitu $0 ; 1,7782 ; 3,1623 ; 5,6235$ dan 10,0002 ppm serta ditambahkan dengan konsentrasi 0 ppm sebagai kontrol. Selanjutnya konsentrasi tersebut digunakan untuk uji utama dan untuk menentukan nilai $\mathrm{Lc}_{50}-24$ jam bahan aktif niklosamida terhadap crustacea. Pada uji toksisitas ini menggunakan 
Aan Fahrizki dkk: Uji Toksisitas Bahan Aktif Niklosamida Terhadap Crustacea Sebagai Water Treatment...

hewan uji yang sama dengan uji penentuan kisaran yaitu PL9 udang vaname \pm 400 ekor serta menggunakan wadah pemeliharaan berupa toples sebanyak 20 buah setiap toples dimasukan 20 ekor hewan uji (densitas 10 ekor/liter) . Berdasarkan penelitian yang telah dilakukan, persentase rasio mortalitas Crustasea yang dihasilkan akibat senyawa aktif niklosamida dengan konsentrasi yang berbeda dapat dilihat pada tabel 2.

Tabel 2. Persentase kematian crustacea selama uji toksisitas bahan aktif niklosamida.

\begin{tabular}{ccccccc}
\hline \multirow{2}{*}{$\begin{array}{c}\text { Konsentrasi } \\
(\mathrm{ppm})\end{array}$} & $\begin{array}{c}\text { 仿ewan uji } \\
(\mathrm{ekor})\end{array}$ & 0 & 1 & 6 & 12 & 24 \\
\cline { 3 - 7 } & 80 & 0 & 0 & 0 & 0 & 0 \\
1,7783 & 80 & 0 & 0 & 2,5 & 3,75 & 5 \\
3,1623 & 80 & 0 & 7,5 & 11,25 & 28,75 & 35 \\
5,6235 & 80 & 0 & 18,75 & 30 & 52,5 & 61,25 \\
10,0002 & 80 & 0 & 66,25 & 88,75 & 97,5 & 100 \\
\hline
\end{tabular}

Perlakuan pemaparan senyawa aktif niklosamida terhadap rasio mortalitas Crustasea dilakukan selama 24 jam dan kemudian diamati mortalitas Crustasea. Berdasarkan hasil pengamatan dengan visual menunjukkan bahwa adanya perbedaan antar perlakuan. Dari tabel tersebut diatas terlihat bahwa mortalitas Crustasea dengan persentase tertinggi terdapat pada perlakuan E yaitu mencapai $100 \%$ dengan perlakuan konsentrasi senyawa aktif niklosamida sebesar 10,0002 ppm. Namun pada perlakuan A (kontrol) dengan konsentrasi metil metsulfuron 0 ppm tidak didapatkan mortalitas (0\%) sedangkan rasio mortalitas Crustasea pada perlakuan B $(1,7783 \mathrm{ppm})$, C $(3,1623$ ppm) dan D (10,0002 ppm) masing-masing mencapai 5\%, 35\% dan 61,25\%. Untuk mengetahui hubungan perlakuan senyawa aktif niklosamida dengan konsentrasi yang berbeda terhadap mortalitas Crustasea dapat dilihat pada gambar 1.

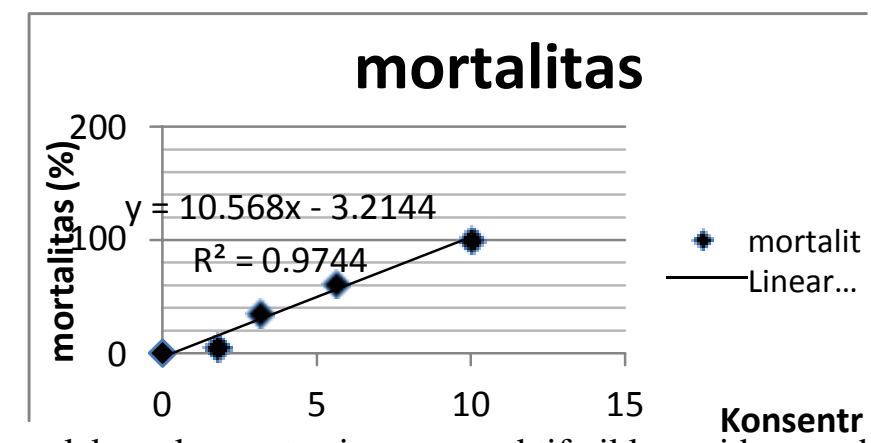

Gambar 1. Hubungan perlakuan konsentrasi senyawa aktif niklosamida yang berbeda terhadap rasio mortalitas Crustasea.

Berdasarkan hasil penelitian yang telah dilakukan, terlihat bahwa semakin tinggi konsentrasi niklosamida yang dipaparkan pada hewan uji (Crustasea.) maka akan semakin tinggi pula mortalias Crustasea (gambar 1). Berdasarkan persamaan regresi linier pada gambar 1 maka diketahui bahwa $\mathrm{Y}$ $=10,56 \mathrm{x}-3,214$ yang berarti bahwa setiap kenaikan $1 \mathrm{ppm}$ konsentrasi niklosamida akan menaikkan rasio mortalitas Crustasea sebanyak $10,56 \%$. Koefisien diterminasi dengan $\mathrm{R}^{2}$ simbol merupakan proporsi variabilitas dalam suatu data yang dihitung didasarkan pada model statistik. Dalam hubungannya dengan korelasi, maka $\mathrm{R}^{2}$ merupakan kuadrat dari koefisien korelasi antara variabel yang digunakan sebagai predictor $(\mathrm{X})$ dan variabel $(\mathrm{Y})$ yang memberikan respon. Nilai $\mathrm{R}^{2}$ pada 
gambar 1 didapatkan sebesar 0.974 hal ini menjelaskan bahwa rasio mortalitas Crustasea 97,4\% yang dipengaruhi oleh konsentrasi senyawa aktif niklosamida, sedangkan 2,6\% dapat diakibatkan oleh faktor-faktor lain seperti kondisi lingkungan.

\section{Kualitas Media Uji}

Untuk melihat kelayakan kualitas air selama uji penentuan kisaran maka dilakukan pengukuran kualitas air meliputi DO (Dissolved Oxygen), suhu, pH dan salinitas setiap pengamatan dilakukan. Hasil pengukuran kualitas air disajikan pada tabel 3.

Tabel 3. Data kualitas air uji DO (Dissolved Oxygen), suhu, pH dan salinitas setiap pengamatan

\begin{tabular}{lcccccc}
\hline \multicolumn{1}{c}{ Parameter } & \multicolumn{5}{c}{ Konsentrasi $(\mathrm{mg} / \mathrm{L}(\mathrm{ppm}))$} & SNI \\
\cline { 2 - 5 } Kualitas Air & 0 & 1 & 4 & 7 & 10 & $(2006)$ \\
\hline DO & $6,05-6,35$ & $6,1-6,34$ & $5,75-6,31$ & $6,11-6,29$ & $6,08-6,45$ & $>3,5 \mathrm{mg} / \mathrm{l}$ \\
Suhu & $31,3-32,2$ & $31,3-32,2$ & $31,3-32,2$ & $31,3-32,2$ & $31,3-32,2$ & $28,5-31,5$ \\
pH & $8,16-9,1$ & $8,16-8,91$ & $8,16-8,83$ & $8,16-8,93$ & $8,16-9,05$ & $7,5-8,5$ \\
Salinitas & $31,1-33,6$ & $31,1-32,7$ & $31,2-32,4$ & $32,2-32,7$ & $31,1-32,1$ & $15-25 \mathrm{ppt}$ \\
\hline
\end{tabular}

Sumber : SNI Produksi Udang vannamei (Litopenaeus vannamei), 2006.

Dari tabel di atas dapat dilihat bahwa kualitas air untuk pemeliharaan hewan uji selama pengamatan masih berada pada kisaran optimum apabila dibandingkan dengan data dari (SNI,2006) tentang kisaran nilai optimum kualitas air untuk pemeliharaan udang vaname seperti pada tabel 3 . Sehingga dapat dikatakan bahwa kematian hewan uji disebabkan oleh faktor tunggal yaitu pemberian konsentrasi niklosamida.

\section{Hasil uji detoksifikasi}

Pada uji detoksifikasi ini dilakukan untuk mengetahui waktu luruh yang dibutuhkan niklosamida dalam air yang ditandai dengan tingkat mortalitas hewan uji. Konsentrasi yang digunakan adalah konsentrasi pada uji utama tanpa dilakukan pergantian air. Setiap perlakuan konsentrasi dimasukan 20 ekor perwadah pemeliharaan lalu diamati setiap 24 jam sampai tidak ditemukan kematian hewan uji pada setiap konsentrasi. Laju peluruhan niklosamida dalam air dapat dilihat pada Gambar 2.

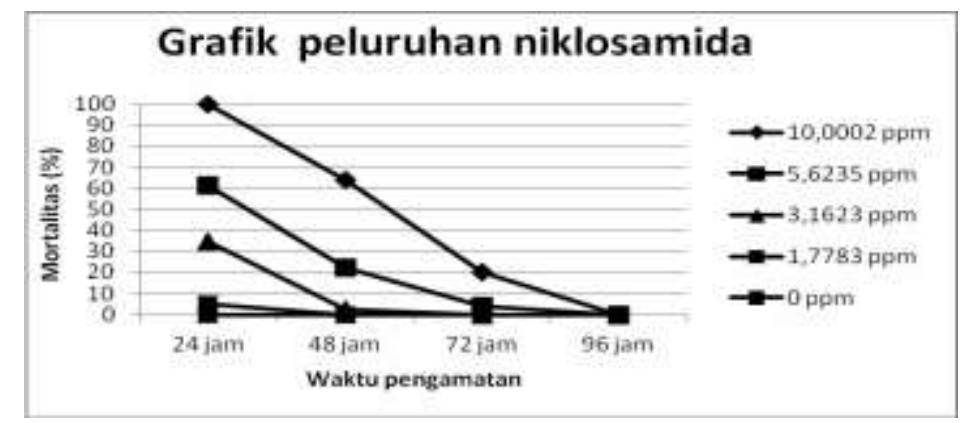

Gambar 2 . Laju peluruhan niklosamida dalam a

Hasil pemaparan Crustacea dengan bahan aktif niklosamida dan dianalisis dengan menggunakan analisis ragam dengan uji $\mathrm{F}$ dan menunjukkan bahwa perlakuan pemaparan bahan aktif niklosamida dengan konsentrasi yang berbeda yang dilakukan selama 24 jam menunjukkan pengaruh yang nyata terhadap mortalitas hewan uji yang dihasilkan $(\mathrm{p}<0.05)$. 
Hasil akhir uji annova menunjukkan bahwa $\mathrm{F}_{\text {hit }}>\mathrm{F}_{\text {tabel }}$, dapat disimpulkan bahwa adanya perbedaan yang signifikan atau beda nyata antara perlakuan (konsentrasi) dengan tingkat mortalitas dengan pola yang postitif dimana semakin tinggi konsentrasi semakin tinggi pula tingkat mortalitasnya. Setelah hasil uji anova menunjukan bahwa adanya perbedaaan antar perlakuan maka dilanjutkan dengan uji lanjut Tukey yang bertujuan untuk mengetahui konsentrasi mana yang paling berpengaruh. Dari uji Tukey didapatkan konsentrasi yang berbeda secara signifikan, yaitu konsentrasi : 3.1623, 5.6235 dan 10,0002 ppm.

Berdasarkan hasil uji definitif (toksisitas) bahan uji yang telah dilakukan, pada perlakuan 0 ppm tidak mengalami kematian, sedangkan pada perlakuan 1,7783 ppm ditemukan persentase kematian hewan uji sebesar $5 \%, 3,1623$ ppm nilai persentase kematian masing-masing sebesar $35 \%$, 5,6235ppm nilai persentase hewan uji sebesar 61,25\% dan perlakuan 10,0002 ppm mejngalami kematian hingga $100 \%$. Peningkatan jumlah persentase kematian crustacea pada berbagai konsentrasi senyawa aktif niklosamida yang berbeda dengan lama waktu pemaparan dapat dilihat pada Gambar 3 .

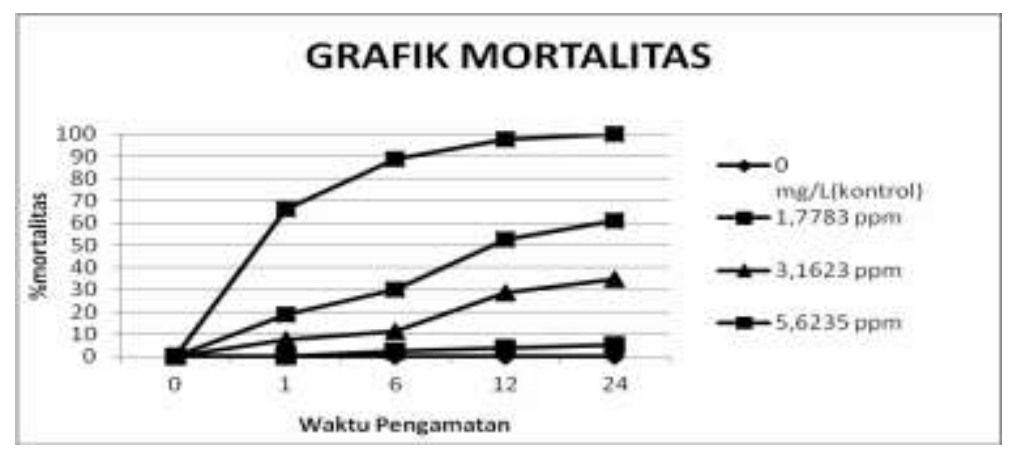

Gambar 3. Grafik mortalitas pada waktu pemaparan yang berbeda

Dengan melihat hasil data yang didapatkan pada Gambar 3, maka analisa probit untuk menentukan nilai $\mathrm{LC}_{50}-24$ jam dapat ditentukan nilainya. Berdasarkan analisa probit diperoleh nilai hasil $\mathrm{LC}_{50}-24$ jam yaitu 3,228 ppm. Hasil pengamatan mortalitas uji utama selama waktu pengamatan selama 24 jam disajikan pada Gambar 3. Ttingkat mortalitas dari hasil uji utama menunjukkan semakin tinggi konsentrasi, semakin tinggi persentase mortalitasnya.

Selain mengamati tingkat mortalitas, pengamatan visual morfologis juga di lakukan untuk mengetahui efek dari bahan aktif niklosamida terhadap hewan uji yang hidup. efek Dari hasil pengamatan secara visual morfologis menunjukan beberapa gejala klinis yang terjadi pada hewan uji, pada kontrol (A) hewan uji secara visual berwarna cerah transparan tanpa ada gejala klinis pada morfologinya, pada konsentrasi B terdapat gejala klinis seperti terdapat bercak merah pada tubuh udang (body necrosis), terdapat necrosis pada pereopod ke 3 dan pleopod ke 2, konsentrasi C semua hewan uji yang masih hidup mengalami body necrosis ditandai dengan bercak merah yang terdapat pada seluruh tubuh hewan uji serta terdapat necrosis pada ujung kaki ke-3 pereopod sementara konsentrasi D warna hewan uji yang masih hidup mulai berwarna putih memucat disertai dengan adanya body necrosis pada seluruh tubuh hewan uji.

Pada konsentrasi E hewan uji mengalami kematian $100 \%$ pada pengamatan 24 jam, gejala klinis pada konsentrasi E terjadi mulai pada pengamatan jam pertama di mana kondisi hewan uji yang mati berwarna putih memucat untuk hewan uji yang masih hidup pergerakan nya sangat terbatas dan hanya berada di dasar toples serta beberapa hewan uji mengalami kejang. Gejala yang demikian menurut Connel dan Miller (1995), merupakan tanggapan yang terjadi pada saat zat fisika atau kimia 
mengganggu proses sel atau sub sel dalam makhluk hidup sampai suatu batas yang menyebabkan kematian secara langsung. Akibat dari keracunan pestisida, ikan ataupun hewan air lainnya dapat stres (Afrianto dan Liviawati, 1992). Body necrosis yang terjadi pada hewan uji menunjukan terjadi gejala stres pada hewan uji. Stres adalah pengaruh beberapa perubahan lingkungan yang memperluas homeostastis atau penstabilan diluar batas normalnya (Esch dan Hansen , 1978 dalam Yousmaniar, 2009) dimana hewan tidak mampu mengatur kondisi fisiologis yang normal karena beberapa faktor merugikan kondisi kesehatannya. Gejala visual morfologis udang disajikan pada gambar 4.

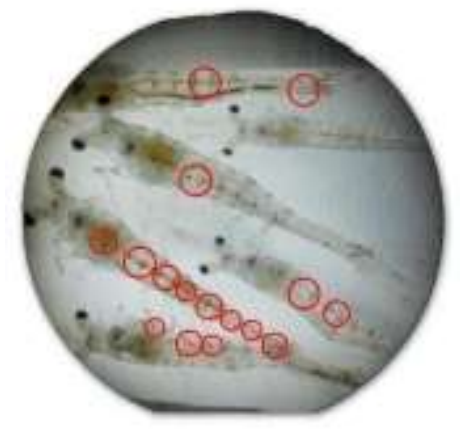

Gambar 4. Gejala klinis body necrosis pada tubuh udang

Pada gambar diatas pengaruh pemberian niklosamida terhadap hewan uji yang menandakan terjadinya body necrosis pada tubuh udang di tandai dengan bercak merah di tubuh udang. Selama uji definitif (uji toksisitas bahan uji) dilakukan juga pengukuran kualitas air, yang bertujuan untuk mengetahui apakah ada faktor lain yang mempengaruhi mortalitas hewan uji khususnya dari faktor lingkungan. Pengukuran kualitas air sama dengan yang dilakukan pada uji penentuan kisaran, meliputi meliputi DO (Dissolved Oxygen), suhu, pH dan salinitas. Hasil pengukuran kualitas air disajikan pada tabel 4 .

Tabel 4. Data kualitas air uji definitif ( toksisitas bahan uji)

\begin{tabular}{lcrrrrc}
\hline \multicolumn{1}{c}{ Parameter } & \multicolumn{5}{c}{ Konsentrasi (mg/L $(\mathrm{ppm}))$} & SNI \\
\cline { 2 - 6 } \multicolumn{1}{c}{ Kualitas Air } & 0 & 1,7783 & 3,1623 & 5,6235 & 10,0002 & \multicolumn{1}{c}{$(2006)$} \\
\hline DO & $5,93-6,36$ & $5,93-6,31$ & $5,65-6,22$ & $5,8-6,21$ & $5,61-6,19$ & $>3,5 \mathrm{mg} / \mathrm{L}$ \\
Suhu & $30,2-31,7$ & $30,2-31,7$ & $30,2-31,6$ & $30,2-31,5$ & $30,2-31,5$ & $28,5-31,5$ \\
pH & $8,05-8,98$ & $8,05-8,91$ & $8,05-9,01$ & $8,06-9,08$ & $8,05-9,07$ & $7,5-8,5$ \\
Salinitas & $31,6-33,9$ & $31,6-33,9$ & $31,5-33,8$ & $31,6-33,9$ & $31,6-33,9$ & $15-25 \mathrm{ppt}$ \\
\hline
\end{tabular}

Berdasarkan hasil pengamatan parameter kualitas air yang telah dijelaskan diatas maka dapat mengindikasikan bahwa mortalitas dan kondisi stress yang dialami oleh hewan uji selama penelitian berlangsung bukan diakibatkan oleh kondisi kualitas air yang buruk namun diakibatkan oleh pengaruh pemaparan bahan aktif niklosamida, hal ini terlihat dari perlakuan (kontrol) yang terlihat tidak ada tanda-tanda terjadinya mortalitas maupun stress.

Dari uji detoksifikasi pada konsentrasi 0 ppm; 1,7783 ppm waktu yang dibutuhkan untuk luruh dalam air adalah 48 jam sementara konsentrasi 3,1623 ppm membutuhkan waktu 72 jam dan 5,6234 dan 10,0002 ppm dibutuhkan waktu 96 jam untuk luruh dalam air hal ini di indikasikan dengan sudah mencapai $100 \%$ SR hewan uji. Hali ini sesuai dengan pernyataan Hendarsih dan Nia ( 2009) yang menyatakan bahwa efektifitas niklosamida hanya bertahan selama tiga hari atau 72 jam setelah perlakuan pada keong mas, namun sesuai dengan penenlitian dari Tanthip Napaumpaiporn (2012) 
Aan Fahrizki dkk: Uji Toksisitas Bahan Aktif Niklosamida Terhadap Crustacea Sebagai Water Treatment...

yang menyatakan bahwa efektifitas niklosamida dalam air berkisar antara 1-4 hari setelah perlakuan pada PL 12 udang vannamei.

\section{KESIMPULAN}

Berdasarkan hasil penelitian dapat disimpulkan bahwa nilai $\mathrm{LC}_{50}$ niklosamida terhadap crustacea sebesar 3,228 ppm dan mempunyai laju peluruhan dalam air selama 96 jam atau 4 hari sehingga dapat menggantikan crustacide dari jenis organoklorin.

\section{DAFTAR PUSTAKA}

Afrianto, E dan Liviawaty, E . 1992. Pengendalian hama dan Penyakit Ikan. Penerbit kanisius Yogyakarta Boyd, C.E. 1982. Water Quality management in Aquaculter and fisheries Scincie ElseverScientific Publishing Company Amsterdam, 312 pp.

Connel \& Miller . 1995. Kimia dan Ekotoksikologi Pencernaan. Penerbit Univ. Indonesia . Jakarta.p 331-341.

Finney. 1971. Probit Analysis. The University Press. Cambridge.

Hendarsih, S \& Nia, K. 2009. Keong Mas, Dari Hewan Pemeliharaan Menjadi Hama Utama di Sawah. BPPAD., 385-403.

Schreier, T. M., Dauson,V. K.,Choi.,Spanjer N. J. A \& M. A. Booguard. 2000.Determinan of niclosanide residue in Rainbow Trout( Oncorhyncus mykiss) and Cannel Catfish (Ictalurus punctatus) fillet tissue by high performance liquid chromatography. J. Agric food Chom.,48:2,212-2,215.

Tanthip Napaumpaiporn., Chalor Limsuwan \& Niti Chuchird. Kasetsart Univesity Fisheries Research Bulletin. 2012. Acute Toxicity of Niclosamide on Creepher Shell (Cerithidea cingulata) and Pacific White Shrimp(Liptopeneaus vannamei) Postlarvae. Bangkok . vol 36 (1)

Worthing . C. H. 1987. The Pestiside Manual. A. World Compendium . Eight Edition Published by the british Crop protection Conncil, 1,088 pp 